\title{
FRONTIER SECURITY IN NORTH EAST AFRICA: CONFLICT AND COLONIAL DEVELOPMENT ON THE MARGINS c. I930-60*
}

\section{Hannah Whittaker}

Brunel University

\begin{abstract}
This article explores colonial development policy on the margins of British East Africa. It argues that much like current development practice in the region, increased colonial interventionism in the years after 1940 was motivated by security interests as well as environmental and economic considerations. Rural interventions were used as a mechanism to 'rein in' what were perceived to be subversive populations, as well as contain potential security threats. The article therefore throws new light on the nature of colonial rural development, as well as the connections between past and present development practice.
\end{abstract}

\section{Key Words}

Kenya, Somalia, northeastern Africa, Eastern Africa, colonial policy, development, environment, pastoralism, violence.

This article examines the colonial history of securitized development on the margins of British East Africa, in what is now the North Eastern Province of Kenya (NEP). During the colonial period, NEP formed the eastern half of what was known as the Northern Frontier District (NFD). This region was an archetypical 'imperial frontier': an example of the remote and barren spaces that existed along the edges of European empires. Imperial frontiers were constructed as zones of exception, and were areas over which political authority was contested and uncertain. ${ }^{\mathrm{I}}$ In more recent history, imperial frontiers, or 'ungoverned spaces' (to use the modern appellation) like northern Kenya, have become key areas of focus for the new securitized development. ${ }^{2}$ As potential security threats, ungoverned spaces are subject to a range of external interventions designed to contribute to the

* The research for this article was supported by a British Academy/Leverhulme small grant, award number SGI5I348. I would like to acknowledge, with thanks, research assistance by Dalle Abraham and Wario Fayo. I am also grateful to Hassan Kochore. I also thank the two anonymous reviewers at The Journal of African History for their constructive comments on an earlier version of this article. Author's email: hannah.whittaker@brunel.ac.uk

I B. Franklin, 'The frontier crimes regulation and frontier governmentality', The Journal of Asian Studies, 74:2 (20I 5), 370; I. Kopytoff, 'The internal African frontier: the making of African political culture', in I. Kopytoff (ed.), The African Frontier: The Reproduction of Traditional African Societies (Indiana, I987), II; R. Reid, Frontiers of Violence in North-East Africa: Genealogies of Conflict since c. I 800 (Oxford, 20II), I2-I3.

2 For a discussion of the securitization of development, see J. Fisher and D. Anderson, 'Authoritarianism and the securitization of development in Africa', International Affairs, 9I:I (20I5), I33-4, (doi: IO.IIII) I468-2346.I2I90). 
process of managing and ending conflict, as well as create secure environments. ${ }^{3}$ There has also been a growth in military and security sector involvement in these development and relief efforts. ${ }^{4}$

In the African context both Western actors and African governments have embraced the securitization agenda. ${ }^{5}$ In Kenya, for example, a United States military task force has been involved in delivering aid and development projects in areas along the border with Somalia since the early 2000s, as part of its regional counterterror and stabilization strategy. ${ }^{6}$ The Kenyan state is also currently engaged in infrastructure development across its northern borderland in an effort to gain control over a previously peripheral territory and combat insecurity. ${ }^{7}$ A number of other regimes in eastern Africa have also adopted militarized practices (including using the military to capture 'ungoverned' spaces and repress internal dissent), in the name of state-led development. ${ }^{8}$

Despite the perceived novelty and increasing articulation of the new securitized development (which includes the institutionalization of stabilization operations by a number of Western governments), it is a new iteration of older ideas and practices. ${ }^{9}$ For example, it is well established that during colonial counterinsurgency campaigns in the r94os and I950s, development was used to pacify populations and win over 'hearts and minds' (to use a common cliché). ${ }^{\text {IO }}$ There was also a security rationale behind the practice of international development that emerged during the I950s, which was a response to popular mobilizations in the global south, and was linked to counterinsurgency and security imperatives during the Cold War. ${ }^{\mathrm{II}}$ Technical assistance was used by the superpowers to secure the strategic assistance and loyalty of smaller states. ${ }^{\text {I2 }}$

The historical longevity of the connections between development and security reflects broader links that have been drawn between colonial and modern development thought and practice. ${ }^{\mathrm{I} 3}$ Many of the notions and strategies of colonial developers have consciously

3 M. Duffield, Global Governance: New Wars and the Merging of Development and Security (London, 200I), 35 .

4 J. Rock, 'Militarized humanitarianism in Africa', Foreign Policy in Focus, (http://fpif.org/militarizedhumanitarianism-africa/), I4 May 20I4.

5 Fisher and Anderson, 'Authoritarianism', I3 I; T. Hagmann and F. Reyntjens (eds.), Aid and Authoritarianism in Africa: Development without Democracy (Chicago, 2016).

6 Between 2003 and 2009, the US Combined Joint Task Force-Horn of Africa implemented I 5 I projects covering veterinary, health, education, and water services. M. Bradbury and M. Kleinman, Winning Hearts and Minds? Examining the Relationship between Aid and Security in Kenya (Medford, MA, 2009), 4.

7 For details of the current infrastructure development, see A. Browne, LAPSSET: The History and Politics of an Eastern African Megaproject (London, 2015).

8 Fisher and Anderson, 'Authoritarianism', I3 I; W. Jones, R. Soares de Oliveira, and H. Verhoeven, 'Africa's illiberal state-builders', Working Paper no. 89 (Oxford, 20I3), I I-I6.

9 S. Barakat, S. Deely, and S. A. Zych, "A tradition of forgetting”: stabilization and humanitarian action in historical perspective', Disasters, 34:3 (2010), 297-3 I9, (doi: I0.I I I I/j.I467-77 I 7.2010.0I 207.x).

Io D. Anderson, Histories of the Hanged: The Dirty War in Kenya and the End of Empire (London, 2005); K. Hack, 'Everyone lived in fear: Malaya and the British way of counterinsurgency', Small Wars and Insurgencies, 23:4-5 (2012), 671-99, (doi: 10.1080/095923 I8.2012.709764).

I I T. Murray Li, The Will to Improve: Governmentality, Development and the Practice of Politics (London, 2007), 8.

I2 A. K. McVety, Enlightened Aid: US Development as Foreign Policy in Ethiopia (Oxford, 20I2), 6I.

I3 M. Berger and H. Weber, Rethinking the Third World: International Development and World Politics (Basingstoke, 2014), 24-5. For some, the whole notion of development is a reflection of Western hegemony 
or unconsciously been taken over by postcolonial governments, international aid agencies, and development experts. The lasting legacy of the colonial period can be seen in things like concerns about the low productivity of peasant agriculture, the dangers of soil erosion, and environmental degradation, as well as the adoption of conservationist policies. ${ }^{\mathrm{I} 4}$ By tracing the colonial history of securitized development on the margins of British East Africa, this article provides new evidence of additional continuities. Much like current development in the region, colonial rural interventions were used as a mechanism to 'rein in' what were perceived to be subversive populations, as well as contain potential security threats. Military and police power was also used to enforce what were ultimately coercive resource management policies, in an attempt to prevent conflict, stabilize populations, and develop internal security.

Examining the historical links between development and security also provides fresh perspective on the nature of colonial rural development. Hitherto, historians have focused on the environmental and economic motivations that drove colonial interventions in the years after I945, as well as the ways in which these interventions reinforced (and undermined) social and political control. ${ }^{\mathrm{I} 5}$ There is also now a large and nuanced literature that deals with the wider international influence of environmental and natural sciences on development planning. ${ }^{16}$ This has not only documented the emergence and evolution of a set of perceived wisdoms about the causes and solutions to environmental change in the African context, but also the ways in which colonial policy contributed to problems such as land degradation. ${ }^{\mathrm{I} 7}$

Environmental and economic considerations were important motivations for colonial development planning. But what this article intends to show is that security could trump both. In the case of NEP, land utilization surveys may have documented pasture being 'destroyed by over-grazing and soil erosion', or water being contaminated by 'bad water

over the rest of the world, and is therefore a new form of colonialism. See A. Escobar, Encountering Development: The Making and Unmaking of the Third World (Oxford, I995).

I4 D. Anderson and R. Gove (eds.), Conservation in Africa: Peoples, Policies and Practice (Cambridge, I989); M. Leach and R. Mearns (eds.), The Lie of the Land: Challenging Received Wisdom on the African Environment (Oxford, I996).

I 5 R. Austen, African Economic History: Internal Development and External Dependency (Oxford, I987), I97; Berger and Weber, Rethinking, 25; F. Cooper and R. Packard, 'Introduction', in F. Cooper and R. Packard (eds.), International Development and the Social Sciences: Essays on the History and Politics of Knowledge (Berkley, I997), 7 .

I6 See, for example, D. Anderson, 'Depression, dust bowl, demography and drought: the colonial state and soil conservation in East Africa during the I930s', African Affairs, 83:332 (I984), 32I-43; W. Beinart, 'Soil erosion, conservationism and ideas about development: a southern African exploration, I900-I960', Journal of Southern African Studies, I I: I (I984), 52-83; C. Bonneuil, 'Development as experiment: science and state-building in late colonial and postcolonial Africa, I930-I979', Osiris, I5 (2000), 258-8I; J. M. Lee and M. Petter, The Colonial Office, War and Development Policy: Organization and the Planning of a Metropolitan Initiative (London, I982).

I7 J. Fairhead and M. Leach, 'Desiccation and domination: science and struggles over environment and development in colonial Guinea', The Journal of African History, 4I:I (2000), 29-33; M. Leach and R. Mearns, 'Environmental change and policy: challenging received wisdom in Africa', in Leach and Mearns (eds.), Lie of the Land, I-33; M. Shanguhyia, 'British war-effort programme and the making of the land degradation narrative in colonial western Kenya', Journal of Colonialism and Colonial History, I6:2 (20I 5), (doi: IO.I353/cch.20I 5.0028). 
discipline', but they also lay bare official concerns over the 'menace' of 'illegal' migration into the colony, and the need for the proper control of the frontier. ${ }^{\mathrm{I} 8}$

The article is based on a critical re-examination of the Dixey scheme for water and grazing that was implemented in the NFD during the late colonial 'development era'. ${ }^{\text {I9 }}$ The first part of the article provides a brief outline of the early colonial social and political geography of the NFD, in relation to its status as a frontier. This is necessary for understanding the later emergence of security-focused development. The article then provides an overview of the Dixey water and grazing scheme. On the surface this scheme reflected similar interventions taking place across British Africa at about the same time, and emerged out of broader colonial anxieties about the negative effects of drought and soil erosion on the productivity of African land. ${ }^{20}$ However, as the article shows, the way that the scheme was implemented, including the priorities of the local political officers that were ultimately responsible for development, and the law under which it was enforced, reveals a clear security rationale.

Having established that colonial rural development in NEP was an early example of securitized development, the second part of the article discusses three further parallels between past and present development practice that the historical case study draws attention to. The first is the existence of a disconnect between the stated intentions and actual aims of development. In northern Kenya during the I940s and I950s, local people were told that development was about securing the well-being of the people and territory of the NFD. However, as with other modern examples of securitized development, this rhetoric concealed other political, economic, and strategic interests. The second parallel is the role of experts in development planning. Much like recent stabilization policies, colonial grazing schemes were devised by engineers and geologists, who made use of supposedly neutral, non-political knowledge and expertise in order to 'improve people's lives'. ${ }^{2 \mathrm{I}}$ This article helps to show how experts conceal the disconnect that can exist between the overt and covert aims of development, and it questions a common assumption that as the presence of colonial experts grew, the power and influence of local political and administrative officials was undermined. ${ }^{22}$ Finally the article considers the unintended outcomes, or 'side effects' (to use James Ferguson's term) of development processes. ${ }^{23}$ Interventions that are designed to increase state presence and control populations, or 'broadcast power' as argued by Jeffrey Herbst, can also have opposing impacts on the ground. ${ }^{24}$

I8 Kenya National Archives, Nairobi (KNA) PC/NFD 5/I/8, 'Post-war five-year development plan, Northern Frontier District', I 944, 3-4; KNA PC/NFD 5/I/8, D. C. Edwards, 'Report on the grazing areas of the NFD', I944, I3, 2 I.

I9 M. Van Beusekom and D. Hodgson, 'Lessons learned? Development experiences in the late colonial period', The Journal of African History, 4I:I (2000), 29.

20 See, for example, D. Anderson, Eroding the Commons: The Politics of Ecology in Baringo, Kenya, I890-I963 (Oxford, 2003); Beinart, 'Soil erosion'; and J. C. McCann, Green Land, Brown Land, Black Land: An Environmental History of Africa, I800-I990 (Oxford, I999).

2 I Li, Will to Improve, 2.

22 J. Hodge, Triumph of the Expert: Agrarian Doctrines of Development and the Legacies of British Colonialism (Ohio, 2007), 227.

23 J. Ferguson, The Anti-Politics Machine: 'Development': Depoliticization, and Bureaucratic Power in Lesotho (Minneapolis, I994), 255.

24 J. Herbst, States and Power in Africa: Comparative Lessons in Authority and Control (New Jersey, 2000), I6I. 
Then, as with now, colonial development on the margins of British East Africa did not so much develop security or reinforce bureaucratic state power, as complicate mobility practices and create new patterns of violence, as some groups of people used violence to make claims over development to the exclusion of others.

\section{THE NFD AND BRITISH FRONTIER ADMINISTRATION, c. 1895-40}

The NFD of Kenya covered an area of approximately ı००,००० square miles. It was situated in the northern half of Kenya, and formed what is now the border region between Kenya, Ethiopia, and Somalia. The NFD was divided into six administrative districts (now called counties): Isiolo, Marsabit, Moyale, Mandera, Wajir, and Garissa, the final three of which constitute present-day NEP. The area is hot and dry, with annual rainfall averaging between five and twenty inches. ${ }^{25}$ Most of the territory that made up the NFD is therefore characterized as low-lying semi-desert, and it is inhabited by multi-ethnic pastoral communities. Of these the Somali are most numerous, and were estimated to comprise about 60 per cent of the total population of the NFD (roughly 200,000) at independence in I963. ${ }^{26}$ Scholars such as Ioan Lewis, have made Somali clan and lineage distinctions central to their understanding of Somali society. ${ }^{27}$ In this article reference is made to Ajuran, Degodia, and Ogaden clan groups (as well as to the Boran, a subgroup of the Oromo people of southern Ethiopia). ${ }^{28}$ However, it is recognized that these distinctions are imprecise and the realities of Somali identity are more fluid than captured in the colonial archive. Clan and lineage distinctions serve as the basis for both Somali unity and division, as clan and extended family networks join or split in a process of 'constant decomposition and recomposition'. ${ }^{29}$

The Somali pastoralists that inhabit the NFD divide the year between wet and dry seasons. The main rains normally fall between April and June, with shorter rains falling between October and December. ${ }^{30}$ However, rainfall patterns are highly variable and fluctuate between good levels and drought years. Rainfall also often varies across different parts of the NFD, with some districts experiencing drought while others do not. For example, in 1935 there was above average rain in Marsabit district ( 35.84 inches), but just 3.62 inches in Garissa. ${ }^{3 \mathrm{I}}$ In Moyale during the same year, no rain fell until May, when six inches fell in one night. ${ }^{32}$ Similarly, in 1939, Isiolo suffered drought conditions while Wajir recorded average rainfall. ${ }^{33}$

The British sphere of influence in eastern Africa was formalized by the Anglo-Italian agreements of I89I and I894. These agreements defined the northern limits of the British East Africa Protectorate (later the Kenya Colony) as the River Daua (though the

25 Command Paper I900, Kenya: Report of the Northern Frontier District Commission (London, I962), 2-3. 26 Ibid.

27 I. M. Lewis, A Pastoral Democracy: A Study of Pastoralism and Politics among the Northern Somali of the Horn of Africa (London, I96I).

28 In footnotes, reference is also made to Aulihan, Garre, and Murille clan groups.

29 V. Luling, 'Come back Somalia? Questioning a collapsed state', Third World Quarterly, I 8:2 (I997), 292.

30 G. Oba, Climate Change Adaptation in Africa: An Historical Ecology (Oxford, 20I4), I84.

3 I KNA PC/NFD I/I/5, 'Northern Province annual report', I935, 48.

32 Ibid. 47.

33 KNA PC/NFD I/I/7, 'Northern Province annual report', I939, I7, 34. 
exact boundary between Kenya and Ethiopia was never fully delineated), and the eastern limit as the River Juba (Jubaland was ceded to the Italians in I925). However, these international borders cut across pastoralists' traditional grazing territories. For centuries before the imperial partition, the NFD, and adjacent parts of Ethiopia and Italian Somalia formed a single economic area. Pastoral mobility and nomadic networks in the region therefore long predated the imposition of colonial boundaries, and many people simply continued to move in and out of the British sphere of influence, regardless of any theoretical restrictions. ${ }^{34}$

From the perspective of the British, the mobility of the inhabitants of the NFD made them difficult to control. The size of the territory, coupled with limited manpower and resources (each district in the NFD only had one or two British administrative officials, who were required to be constantly on the move), was repeatedly used as an excuse for getting 'nothing practical done'. ${ }^{35}$ The NFD lacked exploitable natural resources, and gradually came to be conceived primarily as a buffer zone between the fertile white highlands of Kenya, and the rival imperial powers of Ethiopia and Italy to the north and east. ${ }^{36}$ This was not a region that was thought likely to contribute to the economic prosperity of the colony, and for much of the first half of the twentieth century, local NFD officials argued that the NFD neither 'required' nor 'merited' development. ${ }^{37}$

The British approach to frontier administration corresponded to the broader imperial aim of keeping colonial governance as cost effective and as minimal as possible. ${ }^{38}$ It also reflected colonial attitudes towards the inhabitants of the NFD. As with many other imperial frontiers, NFD officials cultivated an image of the region as an 'ungoverned' space. During the colonial period, the NFD was subject to periodic cross-border raids, and there was conflict and competition between various NFD communities for the control of scarce natural resources. Colonial officials saw this as a 'backward' and unstable place, and the people that lived there gained a reputation as violent and unruly. Sir E. B. Denham, the first governor of Kenya to visit much of the region in 1927, described the inhabitants as 'wild looking men ... the wildest and least disciplined among the Somali'. ${ }^{39}$ On the eve of Kenyan independence, a British government report also referred to the 'volatile character of the Somali', and to the 'tribal feuds, internecine strife; the unsettled frontier lines and the constant raids' that were thought to define life in the NFD. ${ }^{\circ}$

Given the imperative for cost-effective colonial government, as well as the strategic and security considerations that came to determine British occupation of the NFD, early British

34 For detail, see G. Schlee, Identities on the Move: Clanship and Pastoralism in Northern Kenya (Manchester, I989).

35 G. Schlee with A. Shongolo, Islam and Ethnicity in Northern Kenya and Southern Ethiopia (Suffolk, 20I 2), 3 ; KNA DC/MBT 7/I/I, R. W. Hemsted, 'Proposals for the reorganization of the Northern Frontier Province', I929.

36 Schlee with Shongolo, Islam and Ethnicity, 2.

37 KNA PC/NFD 5/I/8, 'Post-war five-year development plan, Northern Frontier District', I944, I.

38 Herbst, States and Power, 58.

39 British National Archives, London (BNA) CO 533/37I/I2, 'Report of Sir E.B. Denham on his tour of the NFD', 1927.

40 BNA FCO I4 I/6840, E. C. Eggins, 'A report on the NFD in relation to internal self-government/independence for Kenya', I96I. 
administration reflected two main priorities. The first was to secure the frontier and halt unchecked and unregulated migration into the colony from areas further north and east. When the British established the first administrative posts in what became the NFD during the first two decades of the twentieth century, a long southwards and westwards migration of Somali people into the region was underway. This migration accounts in part for the instability that was experienced along the frontier, and for fueling concerns about the inherent violence of the region and its inhabitants. The arrival of new groups of Somalis into the area was accompanied by attack and counter-attack between different clan sections, some of whom had guns, as well as Somali attacks on Boran groups for control over wells and grazing. ${ }^{4 \mathrm{I}}$

Second, and in response to conflict between various NFD communities over the control of water and grazing, as well as the movement of people and livestock across international boundaries, the British sought to stabilize the different groups of people living in the NFD to within fixed 'tribal' territories. Colonial governments believed that regulating the movements of pastoralists, and allocating them fixed grazing resources would overcome resource scarcity, which was thought to be the cause of conflict. ${ }^{42}$

In I934, provincial administrators were given additional powers under the Special Districts Administration Ordinance (SDAO) to define 'tribal' grazing areas and penalize those that trespassed. ${ }^{43}$ Any violation of the SDAO was punished by a livestock confiscation or prison sentence, and the administration was given powers of arrest, detention, and the seizure of properties of 'hostile tribes'. Speaking in support of the adoption of the SDAO in NFD areas in 1934, the chief native commissioner described the 'migrations, which bring bloodshed in their train, blood feuds and vendettas, outbreaks of stock diseases, [and] wrongful possession of grazing grounds', as 'the difficulties' that the ordinance was designed to meet. ${ }^{44}$ However, these policies were largely unenforceable. The extent of the administrative deficit in the NFD meant that the authorities faced profound difficulties imposing their vision of territorial 'order', and the pastoralists that were subject to grazing boundaries did their best to circumvent mapped 'tribal' areas. ${ }^{45}$

The British approach to its northern borderland began to change in the years after I940, when the British government passed the Colonial Development and Welfare Act. This made increased funding and manpower available for investment in African colonies as part of an effort to increase economic output and mitigate African demands for greater rights in the context of the Second World War. ${ }^{46}$ There were also heightened expectations

4I H. Moyse-Bartlett, King's African Rifles: A Study in the Military History of East and Central Africa I890-I945 (Aldershot, I956), 2I2, 2I4; Schlee, Identities on the Move, 44; KNA PC/NFD 4/I/I, R. G. Turnbull, 'The impact on East Africa of the Somali and Galla', I958, 6.

42 G. Schlee, 'Territorializing ethnicity: the imposition of a model of statehood on pastoralists in northern Kenya and southern Ethiopia', Ethnic and Racial Studies, 36:5 (2013), 857-74.

43 See, for example, KNA PC/GRS 3/1 $2 / 2$.

44 Hansard, Colony and Protectorate of Kenya Legislative Council Debates, I934, Volume I (Nairobi, I934), $9 \mathrm{I}$.

45 Schlee with Shongolo, Islam and Ethnicity, 3; K. Weitzberg, 'The unaccountable census: colonial enumeration and its implications for the Somali people of Kenya', The Journal of African History, 56:3 (2015), 4I4-I6, (doi: I0.1017/So02185371500033X).

46 Austen, Economic History, 197. 
about imperial responsibilities, which led to new commitments to the modernization of colonial societies. ${ }^{47}$ The NFD, which had previously been regarded as little more than a 'worthless desert', was now subject to 'renewed thought' on the question of development. ${ }^{8}$

\section{THE DIXEY SCHEME}

From I943 to I958, the colonial state of Kenya pursued a major water and grazing improvement scheme in the NFD. The scheme was named after Dr F. Dixey, the geological advisor to the colonial office, and one of the experts who were sent to survey the province and investigate the economic prospects of the region. In particular, the experience of war in Kenya had revealed the NFD to be a potential new market for livestock, and the intention was to unlock what was now considered to be an untapped economic resource. ${ }^{49}$

There were two interrelated problems that needed to be addressed in the NFD: overgrazing, and the uneven distribution of water. Aside from the Tana, Daua, and Uaso Nyiro Rivers, perennial supplies of water in the NFD were limited to a few well fields at Wajir, El Wak, and Moyale, and a small number of isolated wells and springs, for example at Buna and Benane. ${ }^{50}$ Throughout the I930s, district commissioners from across the NFD made reference to the problem of water scarcity, drought, and overgrazing, and believed that the best possible line of progress for the province was to improve existing water supplies. ${ }^{5 \mathrm{I}}$ When the colonial experts visited the region in late 1943 , their assessment of the situation was broadly the same. Both Dixey and D. C. Edwards, the senior agricultural and pasture research officer in Kenya, described in detail the 'extensive' and 'extreme destruction of grazing and soil erosion ... within a range of 20-30 miles of all permanent water'. ${ }^{2}$ In order to open up additional grazing and relieve strain on already denuded areas of pasture, as well as safeguard against recurring drought, both Dixey and Edwards made recommendations for the implementation of grazing control schemes, alongside proposals for increased supplies and better distributed permanent water, without which grazing control would be impossible. ${ }^{53}$ Following a number of small pilot water and grazing projects, the Dixey scheme began in earnest in 1952 , and by 1958 , half a million pounds had been spent on increasing surface supplies of water across the NFD. ${ }^{54}$

In many respects, the Dixey scheme for water and grazing was unexceptional. It was an example of planned development during the late colonial 'development era', when colonial

47 Lee and Petter, Colonial Office, I49.

48 KNA DC/MBT 7/I/I, R. W. Hemsted, 'Proposals for the re-organization of Northern Frontier Province', I929; KNA PC/NFD 5/I/8, 'Post-war five-year development plan, Northern Frontier District', I944, I.

49 KNA PC/NFD 5/ז/8, 'Post-war five-year development plan, Northern Frontier District', I944, 4.

50 KNA DC/WAJ 2/9/I, F. Dixey 'Hydrographical survey of the Northern Frontier District', I 944.

5 I See, for example, KNA PC/NFD 5/I/I I, 'Minute 22 of district commissioners meeting', 20-3 Aug. I929; KNA PC/GRSSA 2/I $3 / I_{7}$, letter from District Commissioner (DC), Garissa, to Provincial Commissioner (PC), Northern Province, 7 July I933; KNA PC/NFD I/I/7, 'Northern Frontier Province annual report', I939, 48.

52 KNA PC/NFD 5/5/I, D. C. Edwards, 'Report on the grazing areas of the NFD', I944, I 2-I6; KNA DC/WAJ 2/9/I, F. Dixey 'Hydrographical survey of the Northern Frontier District', I944, I4.

53 KNA DC/WAJ 2/9/I, F. Dixey, 'Hydrographical survey of the Northern Frontier District', I944, 7, I4-I6; KNA PC/NFD 5/5/I, D. C. Edwards, 'Report on the grazing areas of the NFD', I944, I4, I6-I7.

54 KNA, PC/NFD 5/2/8, H. Humphrey and Sons, The Northern Frontier Province and Water Development Scheme, I950-1958 (Nairobi, I958), 3, 73. 
initiatives for agricultural, administrative, and economic reform touched the lives of colonial subjects to an unprecedented extent. ${ }^{55}$ The evolution of British colonial development doctrine, especially within the colonial office is already well documented. ${ }^{56}$ Suffice to say here that the experience of the Second World War consolidated shifts in emphasis within colonial policy that date to the I930s. The global depression revealed the vulnerabilities of colonial economies at the same time that there was an expansion of scientific and technical knowledge about the demographic, agricultural, and environmental conditions in the colonies. Colonial experts claimed that rapid growth in human and livestock populations, as well as Africans' poor land use practices threatened the natural resources of colonies. ${ }^{57}$ Throughout the I930s and I940s, earlier colonial beliefs in the abundance of Africa's natural resources therefore gave way to concern for the fragility of tropical environments, and the threat of environmental degradation and declining agricultural yields. ${ }^{5}$ These developments encouraged a belief that state intervention was needed to combat the effects of population pressure, overgrazing, and soil erosion, which formed the central focus of the expert thinking behind the Dixey scheme.

Like many other planned development interventions of the late colonial development era, the Dixey scheme for water and grazing was also an example of development failure. The final report noted that 'some' seasonal migrations from wet to dry season pasture had been delayed, and that there had been 'some' recovery of grazing in Mandera and Wajir districts. ${ }^{59}$ However, insufficient water had been made available in each area to implement a proper system of rotational grazing control, and overgrazing 'will in a short time be repeated'. ${ }^{6}$ In August 1959, for example, the district commissioner of Wajir reported that all the district's Ajuran were watering their livestock at Dixey pans constructed at Giriftu, which was 'as barren as it has ever been'. ${ }^{6}$

Scholars such as Gufu Oba and Martin Shanguhyia argue that almost without exception, colonial grazing programmes performed poorly. ${ }^{62}$ Rather than improve standards of living and increase livestock marketing, most contributed to environmental degradation. For example, the compression of pastoralists into smaller areas of land is associated with pasture decay. ${ }^{63}$ Environmental historians have also revealed some of the misguided assumptions that lay behind much colonial conservationist policy. ${ }^{64}$ In particular, questions have been raised about the concept of desertification, and the association of drought

55 This phenomenon has been characterized by Low and Lonsdale as a 'second colonial occupation'. D. A. Low and J. M. Lonsdale, 'Towards a new order, I $945^{-63}$ ', in D. A. Low and A. Smith (eds.), The Oxford History of East Africa, Volume III (Oxford, I976), I2-16.

56 See, for example, S. Constantine, The Making of British Colonial Development Policy, I9I4-I940 (London, I984); Lee and Petter, Colonial Office.

57 Anderson, 'Dust bowl'.

58 Hodge, Triumph, I46-66.

59 KNA PC/NFD 5/2/8, Northern Frontier Water Development Scheme, 79.

60 Ibid. $8 \mathrm{I}$.

6I KNA PC/GRSSA 3/I/I2, 'Wajir district monthly report', Aug. I959.

62 Oba, Climate Change, I82; Shanguhyia, 'British war effort'.

63 W. Beinart, 'African history and environmental history', African Affairs, 99:395 (2000), 274.

64 See Leach and Mearns (eds.), The Lie of the Land. 
with anthropogenic factors. ${ }^{65}$ From this perspective, it was always unlikely that the Dixey water scheme would improve conditions in the NFD, which were determined by local climatic conditions. When Dixey and Edwards visited the NFD to gather evidence of soil type, vegetation, and hydrology, it was during an exceptionally dry spell, after the failure of the rains. ${ }^{66}$ NFD district reports describe 'high winds and dust storms', and not more than 0.Io inches of rain between August and September I943. ${ }^{67}$ Yet, a few months after Dixey and Edwards' visit, 'heavy rain showers' were 'enough to revive grazing'. ${ }^{68}$

Some local NFD officials also expressed skepticism about the ecological 'value' of water and grazing control. In I952, the Wajir district commissioner assessed the progress of pilot grazing schemes in his district, and remarked, 'when it rains the grass grows, when it does not, there is little that can be done' ${ }^{69}$ It was the 'personal' opinion of Richard Turnbull, the provincial commissioner between I948 and I953, that 'the experiments' have 'been no use at all' ${ }^{70}$ His predecessor, Gerald Reece agreed, arguing in I94I that 'the problem of soil erosion as such does not exist to any great extent in the NFD' as 'seasonal moves to new grazing areas as the various water supplies become exhausted do have the benefit of checking overgrazing and the danger of soil erosion. ${ }^{7 \mathrm{I}}$ These factors notwithstanding, behind the failure of the Dixey scheme also lies a more complex and interesting story of the aims and outcomes of development in the NFD as it was translated into practice.

\section{DEVELOPING SECURITY}

In Anthropology and Development, Jean-Pierre Olivier de Sardan describes the development enterprise as an arena in which various logics and strategies come into confrontation..$^{72}$ There is the logic and strategies of the initiators of development, and those of the target population. This article deals with the logic and strategies of the target population later. Among the initiators of development in the NFD there were also two competing logics. The logic and strategies of the technical experts involved in conceiving schemes for improvement, and that of the local political officers responsible for implementing them. In this regard, the reports that Dixey and Edwards produced following detailed soil reconnaissance surveys and hydrology reports contained general recommendations for development, but in the absence of permanent water and pasture officers stationed within each NFD district, provincial and district commissioners ultimately made decisions about where water and grazing needs lay, and they took control of all development

65 M. Mortimore, Adapting to Drought: Farmers, Famines and Desertification in West Africa (Cambridge, I989); J. Swift, 'Desertification: narratives, winners and losers', in Leach and Mearns (eds.), Lie of the Land, 73-90.

66 KNA PC/NFD 3/2/I, 'Wajir district monthly report', Nov. I943.

67 KNA PC/NFD 3/2/I, 'Wajir district monthly report', Aug., Sept., and Nov. I943.

$68 \mathrm{KNA}$ PC/NFD $3 / 2 / \mathrm{I}$, 'Wajir district monthly report', Feb. I944.

69 KNA PC/GRSSA 2/I3/I6, letter from DC Wajir, to PC Northern Province, 26 June I952.

$70 \mathrm{KNA}$ PC/GRS $3 / \mathrm{I}_{2} / 8$, letter from PC Northern Province to Executive Officer, African Land Utilization and Settlement Board, Nairobi, 20 Dec. I952.

7I KNA PC/GRSSA 2/2/8, letter from Officer in Charge, NFD, to Chief Secretary, Nairobi, I 5 Sept. I94I.

72 J. P. Olivier de Sardan, Anthropology and Development: Understanding Contemporary Social Change (London, 2005), I37. 
activity, including the establishment and improvement of water pans and wells, as well as anti-erosion measures. ${ }^{73}$ Through their involvement, local officials obscured the ecological logic of interventions in favour of pre-existing administrative and security considerations. By this time, a census exercise carried out in I93 8 and I940, appeared to confirm long-held 'fears' (described by one former NFD district commissioner as an 'obsession') about the 'threat' of population movements. ${ }^{74}$ Administrative officials reported that less than half of the Somali counted in Isiolo district, the gateway between the NFD and the rest of the colony, were born in Kenya, or were legally entitled to be there. The other half was believed to have 'infiltrated' from British or Italian Somaliland. ${ }^{75}$

That colonial rural development policies in the NFD were used to serve a broader purpose of disciplining and controlling what local officials believed to be unruly Somali pastoralists is evident, first and foremost, by the way that supposedly 'environmental' policies were enacted (a discussion of the security discourse of development is made below). This entailed the strategic establishment of new water supplies, sometimes without regard for topography or water catchment, avoiding locations that might encourage unwanted crossborder movements. In June I948, a Shell-BP borehole that was dug during oil exploration in Liboi, near the border between Kenya and Italian Somalia was not converted into a pan that could be used by local people without the need for a mechanical pump. The principle reason given by the provincial commissioner was that the borehole was situated too near the frontier for people to be left to use it at their will. The mechanical pump gave the administration the ability to control the supply of water and therefore shut it down if it attracted use by people from across the border. ${ }^{76}$ A year earlier, Turnbull also refused permission for improvements to be made to a pan in Degodia salt bush grazing at Yago in Wajir district because it 'encouraged' Degodia 'trespass', a constant source of colonial anxiety, into grazing further west. Turnbull wanted the pan 'done away with', rather than improved. ${ }^{77}$

A group's access to grazing was also mediated by the security interests of the administration. It was common practice for local officials to agree to temporary border adjustments and grazing concessions for those experiencing periods of extended or particularly severe drought within their 'usual' grazing territory. However, these kinds of concessions were tenuous and never guaranteed, especially after I945. Being granted a grazing concession required an established record of 'good behavior' or 'loyalty' to the administration. The Jibrail section of the Degodia in Wajir was given a temporary pass to use salt bush in the El Lass area of the district in December I948, because their chief was 'strong' (read had influence over his section) and 'plays the game'. ${ }^{78}$ But two Boran

73 KNA PC/GRSSA 2/I3/I 8, letter from Crown Counsel, Nairobi to PC Northern Province, 29 Nov. I948.

74 C. C. Trench, The Desert's Dusty Face (London, I964), 8. For a discussion of the unreliability of colonial census data, see Weitzberg, 'Census'.

75 KNA PC/EST 2/I I/I6, The Secretariat, 'The position of Alien Somalis in Kenya Colony', 25 Apr. I945.

76 KNA DC/GRSSA 6/3, letter from PC Northern Province to J. Webster, Public Works Department, Nairobi, I 4 June I948.

77 KNA PC/GRSSA 2/I3/I6, letter from PC Northern Province to DC Wajir, I3 Oct. I948.

78 KNA PC/GRSSA 2/I3/I6, letter from DC Wajir to PC Northern Province, 27 Dec. I948. 
villages facing drought and 'starvation' in Isiolo district were refused permission to graze in Wajir because they did not consult 'properly' with administrative officials. ${ }^{79}$

The process of establishing and improving wells, pans, and boreholes under the Dixey scheme also resulted in increased administrative capacity. Two hundred and five miles of new road (what Herbst describes as the 'tentacles' or 'sinews' of state power) was constructed, and a further 9 Io miles of existing road was repaired across the NFD. ${ }^{80}$ The process of planning interventions produced a plethora of maps that documented the locations of water supplies, both old and new, as well as the boundaries that were supposed to mark the extent of clan based grazing zones. To assist with the enforcement of development schemes, local chiefly authorities were also expected to inform British officials about individuals or groups of people from within their own or neighboring communities that failed to comply with grazing or movement restrictions. ${ }^{8 \mathrm{I}}$

Schemes for water and grazing control were formalized as security measures when the SDAO became the mechanism for enforcement. Under section $17 \mathrm{~b}$ of the ordinance, 'whenever it appears expedient', the provincial commissioner was able to 'prohibit the use by any tribesmen of any specific grazing or other areas of water'. ${ }^{82}$ The SDAO also enabled the provincial administration to employ local grazing guards that were recognised by law as an armed force. ${ }^{83}$ Grazing guards assisted the police by patrolling water supplies and grazing boundaries, and handed out communal punishments when individuals or groups of people were found to have crossed resource borders without the permission of local officials. ${ }^{84}$ Fines issued under the SDAO were then used to pay for additional water development works. ${ }^{85}$

Use of the SDAO to legislate development initiatives was administratively convenient, but it was no accident. The SDAO was originally modeled on the Indian Frontier Crimes Regulation, which was used to administer the North West Frontier of India, and was adopted in Kenya in I934, to deal with the conditions of administration in Kenya that were specific to the NFD (though the SDAO was also applied to various other Kenyan districts during exceptional circumstances, such as the Emergency). ${ }^{86}$ In particular, the SDAO formalized the I909 Collective Punishments Ordinance, a form of communal governance that was used across the British Empire, whereby colonial subjects were treated

79 KNA PC/GRSSA 2/I3/I6, letter from Officer in Charge, NFD to DCs Isiolo and Wajir, 20 June I945; KNA PC/GRSSA 2/I3/I6, letter from DC Wajir to Officer in Charge, NFD, 30 June I945.

80 KNA PC/NFD 5/2/8, Northern Frontier Water Development Scheme, 42, 47, 54; Herbst, States and Power, 84. For a critique of Herbst, see H. Kochore, 'The road to Kenya?: visions, expectations and anxieties around new infrastructure development in northern Kenya', Journal of Eastern African Studies, I0:3 (2016), 494-510, (doi: 10.1080/I7531055.2016.1266I98).

8 I See, for example, KNA DC/ISO 4/7/9, letter from DC Garissa to Assistant Inspector of Police, Balamballa, 23 Oct. I953.

82 KNA PC/GRSSA 2/I3/I 8, letter from PC Northern Province to J. H. Lewis, Commissioner for African Land Utilization and Settlement Board, Nairobi, 29 Oct. I948.

83 KNA PC/GRSSA 2/I3/I 8, letter from PC Northern Province, to J. H. Lewis, Commissioner for African Land Utilization and Settlement Board, Nairobi, I9 Oct. I948.

84 KNA PC/GRSSA 2/20/5, letter from PC Northern Province to DC Wajir, 25 Apr. I949; KNA PC/GRSSA 3 /I/ I I, 'District Commissioner Mandera, safari diary', 7-9 July I950; KNA DC/ISO 4/7/9, letter from DC Garissa to Assistant Inspector of Police, Balamballa, 23 Oct. I953.

85 See, for example, KNA PC/NFD I/I/ı。, 'Northern Frontier Province annual report', I95 I, 49; KNA PC/NFD I/I/I I, 'Northern Frontier Province annual report', I955, 2 I.

86 Hansard, Legislative Council Debates, 90-I. 
and governed as members of discrete communities. ${ }^{87}$ By collectively policing and punishing communities through the SDAO, the British believed that they were replicating indigenous categories of identity, which were seen as a source of stability. ${ }^{88}$ In his influential I943 report into NFD pastures, Edwards blamed unchecked Somali migration into Kenya for leaving the people there in a state of 'flux', and without a 'strong sense of tribal organization' ${ }^{89}$ By the latter stages of the decade, the Somali Youth League, a pan-Somali political association, was also being blamed for teaching people that 'an Eldorado will be achieved by abolishing tribal authority and tribal boundaries' so that 'anyone can graze and go where he likes'. ${ }^{\circ}$ The enforcement and management of grazing control measures on a 'tribal' basis was therefore seen as a way to consolidate 'traditional' forms of identification, and were a useful method for clearly establishing 'which group could be held responsible for a particular area'. ${ }^{\mathrm{I}}$ Overall, NFD development policy increasingly narrowed away from what could be done for the condition of the rangeland and for the economic prosperity of the NFD, towards how such initiatives could be used to 'anchor' the population (to use Reece's words) within the region, and therefore help to develop security. ${ }^{92}$

\section{COLONIAL CONTINUITIES AND DEVELOPMENT DISCONNECTS}

So far, this article has outlined the guiding principles of frontier administration in the NFD, and it has detailed the major colonial scheme for improvement that was implemented there during the late colonial development era. The article has also shown that overall, the Dixey scheme for water and grazing was an early example of securitized development. Colonial development in the NFD prioritized security objectives and was focused in an area where the threat of conflict and instability was seen to predominate. Interventions were also assisted by military and police power, and enabled actions to be taken against both domestic and cross-border threats. ${ }^{93}$

Analyzing the Dixey scheme through the lens of security also helps to shed light on three further parallels between colonial and modern-day development. The first is the existence of a disconnect between the stated intentions and actual aims of development. This is something that is repeatedly noted in respect of Western development, which is at least rhetorically, about improving people's lives (for example, by fighting poverty or promoting peace). This is not to say that humanitarian concerns are not an important component of development, or that there are no genuine attempts to improve people's lives, but scholars have repeatedly pointed to the fact that interventions are actually about the economic, strategic,

87 Franklin, 'Frontier crimes', 373.

88 Ibid. 374.

89 KNA PC/NFD 5/5/I, D. C. Edwards, 'Report on the grazing areas of the NFD', I944, I3.

$90 \mathrm{KNA}$ PC/GRSSA 2/I $3 / \mathrm{I} 8$, letter from PC Northern Province to J. H. Lewis, Commissioner for African Land Utilization and Settlement Board, 30 Apr. I948. For more on the Somali Youth League, see C. Barnes, 'The Somali Youth League, Ethiopian Somalis and the Greater Somalia idea, c. 1946-48', Journal of Eastern African Studies, I:2 (2007), 277-9I, (doi: I0.I080/I753 I05070I452564).

9I KNA DC/GRSSA 6/3, letter from Officer in Charge, NFD, to DC Wajir, I2 Feb. I944.

92 KNA PC/NFD 5/I/8, 'Post-war five-year development plan, Northern Frontier District', I944, 3.

93 These are all characteristics of the securitization of development. Fisher and Anderson, 'Authoritarianism', I33-4. 
or other value that is derived (overtly or covertly) by the developer. ${ }^{94}$ For instance, US military assistance in northern Kenya during the early 2000 s was aimed at helping develop indigenous capacity to secure essential services. Along with the rest of the Horn of Africa, this is a strategic area perceived to be at risk of violent extremism and political instability. ${ }^{95}$ Interventions were therefore part of a process of 'security exporting' to promote US national interests overseas. ${ }^{96}$

A similar point can be made with regards to Kenyan national development. Embodied within Kenya Vision 2030, the country's blueprint for development is a commitment to providing development and economic opportunities for northern Kenya. ${ }^{97}$ The vision statement reads: 'A secure, just and prosperous northern Kenya and other arid lands, where people achieve their full potential and enjoy a high quality of life. ${ }^{98}$ Alongside infrastructure, public services, and land reform, meeting the threat of insecurity is a key priority articulated within the document. ${ }^{99}$ However, there are also regional oil and gas prospects, and from the perspective of the government, combatting insecurity and developing infrastructure is important if potential investors are to be wooed. Northern Kenya has also recently emerged as a key 'swing' region in national elections, and the promise of development can help to secure votes. ${ }^{\text {Ioo }}$

The colonial water and grazing schemes implemented in northern Kenya also provide a clear example of the disconnect that can exist between the stated intentions and real aims of development. Official rhetoric surrounding the Dixey water scheme and its associated grazing control measures focused on the need to increase water supplies and eliminate soil erosion in order to protect people, livestock, and grazing from the threat of drought. Local people were made aware of these ambitions in barazas (public meetings) with district officials, where a number of chiefs and headmen expressed interest in projects to improve water supplies. ${ }^{\text {IOI }}$ Throughout the interwar years, local officials were also clear about the devastating effects that drought had on people's lives, including livestock loss, poverty, and starvation. ${ }^{\text {IO2 }}$

However, the main consideration within confidential development plans produced by provincial and district officials was the effect that drought and conditions of poor grazing

94 H. Zimmermann, 'Exporting security: success and failure in the securitization and desecuritization of foreign military interventions', Journal of Intervention and Statebuilding, I I (20I7), 225-44, (doi: I0.1080/ I7502977.20I7.I3I0I74). For a more historical approach, see McVety, Enlightened Aid.

95 Bradbury and Kleinman, Winning, 8.

96 Ibid. I 5-I6; Zimmermann, 'Exporting security', I.

97 Bradbury and Kleinman, Winning, 8.

98 Government of Kenya, Vision 2030 Development Strategy for Northern Kenya and Other Arid Lands (Nairobi, 20II), I.

99 Ibid. I2-13, I 8, 27-9.

Io० For example, since 2013 the incumbent president has made a number of visits to the northeast and has invested in homes, schools, and electricity supply. J. Ng'etich, 'Uhuru and Raila fight for 3.7 million votes that could tilt the scales', Standard Digital (Nairobi), 3 June 20I7. Also see N. Carrier and H. Kochore, 'Navigating ethnicity and electoral politics in northern Kenya: the case of the 2013 election', Journal of Eastern African Studies, 8:I (20I4), I35, (doi: I0.1080/I753 I055.20I3.87II 8I).

IoI KNA PC/GRSSA $3 /$ I/I I, see the numerous safari reports and diaries of the DC Mandera. Also see KNA DC/ WAJ 2/9/I, Survey of the Lower Uaso Nyiro with Dr Dixey, I I Oct. I943.

IO2 For a couple of examples, see KNA, PC/NFD I/I/3, 'Northern Frontier Province annual report', I928; KNA PC/NFD I/I/7, 'Northern Frontier Province annual report', I939, 48. 
had on the (in)ability of officials to control movement and keep pastoralists within their allotted grazing areas, as well as its bearing on the continued southwards migration of Somalis from areas further north. ${ }^{\mathrm{IO} 3}$ Gerald Reece, one of the strongest advocates of the Dixey scheme argued in I945 that the only solution to the 'serious menace' of Somali movement southwards was 'to improve the desert area where the Somalis live' ${ }^{\text {I04 }}$ Reece was also clear about the need for more clearly defined and enforced grazing areas. ${ }^{\text {I05 }}$ Reece's hope was that by organizing grazing units so that each area was economically selfsufficient, the need for people to move between areas, and across the frontier would be minimized. ${ }^{106}$ Although Reece acknowledged that this would be a difficult task, given traditional pastoralist adaptive strategies that require mobility over long distances, he was also adamant that it was wrong to spend half a million pounds on the Dixey scheme unless 'we are able to control properly the people that are likely to use the new wells' ${ }^{\text {I07 }}$ His successor, Richard Turnbull agreed. 'If it becomes widely known that effective control is not exercised in our territory', he wrote in I949, 'then we can expect increased immigration from Somalia.' ${ }^{\text {I08 }}$

British administrators serving in the NFD were well aware of the ecological imperative that lay behind many cross-border movements of people and livestock. In I907, the British concluded an agreement with the Ethiopian authorities that gave the subjects of both authorities the right to access water and pasture in the territory of the other. ${ }^{\text {I09 }}$ Just as inhabitants of Ethiopia and Italian Somalia moved into the NFD, many people that the British considered to be 'normally resident' in the colony, also periodically moved out, depending on climatic conditions. I IO However, these local officials also feared that migrating pastoralists would quickly force their way into the already overpopulated districts of Kenya and put pressure on the white highlands. ${ }^{\text {II }}$ They also blamed the exercise of trans-frontier grazing rights for enabling cross-border raids into Kenyan territory. ${ }^{\text {II } 2}$ Safeguarding the region's water and pasture resources was therefore the means to a different end: secure and protect the economically more important areas of the colony.

\section{EXPERTS AND ADMINISTRATORS}

The second and related parallel between past and present development practice is the role of experts. Scholars such as Joseph Hodge have already traced the colonial origins of an

I03 KNA PC/NFD 5/I/8, 'Post-war five-year development plan, Northern Frontier District', I944, 9, 2I. Earlier NFD officials also connected water scarcity to the problem of movement control. KNA DC/GRSSA 8/I, letter from PC Northern Province to Chief Native Commissioner, Nairobi, 3 I Oct. I93 I.

Iо4 KNA PC/NFD 5/I/8, 'Post-war five-year development plan, Northern Frontier District', I944, 3.

I05 Ibid. 27

I06 Ibid. I4.

I07 KNA PC/GRSSA 2/I $3 / 18$, letter from Officer in Charge, NFD, to all DCs, 4 July I945.

Io8 KNA PC/GRSSA 2/20/5, letter from PC Northern Province, to DC Wajir, 25 Apr. I 949.

Io9 KNA PC/NFD 5/I/I, 'Note on the Ethiopian frontier', II Oct. I944; KNA PC/NFD 5/I/8, 'Post-war five-year development plan, Northern Frontier District', I944, 2.

I Io KNA PC/NFD 3/2/I, monthly intelligence reports for I930s.

I I I KNA PC/NFD 5/I/I, 'A five year plan for Moyale district', I944, I I.

I 2 KNA DC/WAJ 2/9/I, F. Dixey, 'Hydrographical survey of the Northern Frontier District', I944, 6. 
alliance between scientific expertise, development, and the exercise of state power. ${ }^{\mathrm{II} 3}$ During the first half of the twentieth century, British colonialism displayed a growing confidence that policies informed by scientific and technical experts could develop the empire's resources and manage economic and environmental problems.

In the modern context a number of scholars have also dealt with the prevalence, power, and influence of scientific and technical experts within development practice. ${ }^{\text {II } 4}$ Within this literature, the utility of experts lies in their ability to translate what Tania Murray Li calls 'the will to improve' - the desire of governments or development agencies to secure the well-being and improve the conditions of populations - into explicit programmes of action. Specifically, experts frame problems to be addressed in technical terms so that specific technical interventions can be devised. Often the problem is understood in terms of what is lacking from a specific place or behaviour, which enables the experts to supply a technology to provide what is missing. In this regard, there is a technocratic logic to current stabilization operations. Humanitarian experts frame conflict and instability as being the result of some sort of governmental weakness, the solution to which can be found in external support for the provision of public services and infrastructure (sometimes referred to as 'capacity building'). ${ }^{\text {I } 5}$

By framing problems to be addressed in technical terms, experts have also been shown to depoliticize schemes for improvement. For example, terms like 'capacity building' provide a sense of stabilization being apolitical. The approach is converted into key deliverables, budgets, and infrastructure. ${ }^{\mathrm{I} 6}$ Experts therefore help to replace a rationality of politics with a rationality of science and technology, and recast political problems in the neutral language of science. In this sense, experts both mask the political aims of development, and place the political character of decision-making at one remove from government. Whatever the original intention the developer has for an intervention, experts are useful because they provide a neutral 'scientific' justification for that intervention.

The tendency to reframe political issues as technical development challenges is a feature of international aid and colonial development. In the case of the NFD, colonial experts saw soil erosion as a consequence of Africans' poor land use practices, in particular overgrazing and overstocking. Their solution was to increase supplies of water (thereby opening up new areas of pasture to grazing), and implement grazing schemes that allocated specific people to specific areas of land with limited numbers of stock. ${ }^{\text {II } 7}$ In making these recommendations, which were in essence about environmental conservation, the experts provided colonial officials with the means to establish and extend existing population control measures, as embodied by the SDAO, and they made political decisions about the reallocation of water and pasture resources part of a technical solution to a technical problem.

\footnotetext{
I 3 Hodge, Triumph.

I 4 Ferguson, Anti-Politics; Li, Will to Improve. For a more critical perspective, see Sardan, Anthropology and Development.

I 5 P. Fishstein and A. Wilder, Winning Hearts and Minds? Examining the Relationship between Aid and Security in Afghanistan (Medford, MA, 20II), I5; Bradbury and Kleinman, Winning, I3-I6.

I 6 T. Hagmann, Stabilization, Extraversion and Political Settlements in Somalia (Nairobi, 20 I6), I7.

I 7 KNA DC/WAJ 2/9/I, F. Dixey, 'Hydrographical survey of the Northern Frontier District', I944, 7, I4-I6; KNA PC/NFD 5/5/I, D. C. Edwards, 'Report on the grazing areas of the NFD', I944, I4, I6-I7.
} 
Within the literature on colonial era experts, there is however a tendency to assume that as the presence of scientists and technocrats grew, the local knowledge and grounded insights of district level personnel was devalued. ${ }^{\text {II } 8}$ Modern development has also been criticized for failing to pay attention to local conditions or local knowledge. ${ }^{\text {I } 9}$ For example, stabilization has been criticized for providing a 'toolkit for responding to crisis' that requires little knowledge or understanding of the crisis or its context. ${ }^{\text {I20 }}$ Likewise in the NFD, anxieties about soil erosion were shaped by wider imperial debates about the environment, and emerged out of knowledge exchange between British colonial experts and a global network of specialists, many of them drawing on the experience of the 'Dust Bowl' in the southern plains of America. ${ }^{\text {II }}$ However, in the case of northern Kenya, there was no simple knowledge-power regime that favoured the experts. Connections were drawn (and to a large extent still are) by both the technical experts and the administrative officials between environmental degradation, resource competition, and conflict and instability. ${ }^{\text {I22 }}$ Throughout the I930s and I940s, local officials blamed resource scarcity for fueling local conflicts and for encouraging Somali population movements. ${ }^{\text {I23 }}$ They also believed that drought conditions undermined effective enforcement of clan based grazing territories. ${ }^{\mathrm{I} 24}$ When Dixey and Edwards prepared their reports into water and pasture they also made reference to the threat of raids from Ethiopia, control of migration, and pacification of the northern frontier, which they believed had the potential to undermine the success of grazing control. ${ }^{\mathrm{I} 25}$ What is more, the relative freedom that was granted to individuals within the colonial administration to implement development projects in the NFD, meant that local officials were able to use the experts' justifications for actions that they wanted to take but for different reasons.

\section{COLONIAL FAILURES AND DEVELOPMENT DIVERGENCES}

The third parallel between past and present development practice that the Dixey scheme draws attention to is the failure of development interventions to achieve what they set out to do. This criticism has been made with respect to individual development projects, including stabilization and other security-focused approaches to development, and in relation to the entire development industry, which has been repeatedly criticized for its lack of

\footnotetext{
I 8 Hodge, Triumph, 227-9.

I 9 Escobar, Encountering Development, 6, 8; J. Fisher, 'Reproducing remoteness? States, internationals and the co-constitution of aid "bunkerization" in the East African periphery', Journal of Intervention and Statebuilding, I I (20I7), 99, (doi: I0.1080/I7502977.2016.I260209).

I 20 Rift Valley Institute, Stabilization in Eastern and Central Africa: Insights from Somalia, South Sudan and the DRC (Nairobi, 20I7), IO.

I 2 I See Anderson, 'Dust bowl'.

I22 The combination of environmental degradation and resource competition, coupled with marginalization and weak government is regarded as a key cause of conflict and instability by humanitarian and development agencies working in the Horn of Africa. Bradbury and Kleinman, Winning, 25.

I 23 KNA DC/GRSSA 8/I, letter from PC Northern Province to Chief Native Commissioner, Nairobi, 3 I Oct. I93 I; KNA PC/NFD 5/I/8, 'Post-war five-year development plan, Northern Frontier District', I944, 2.

I 24 KNA PC/NFD 5/I/8, 'Post-war five-year development plan, Northern Frontier District', I944, I4, 27.

I 25 KNA PC/NFD 5/5/I, D. C. Edwards, 'Report on the grazing areas of the NFD', I944, I3, 2 I; KNA DC/WAJ 2/9/2, F. Dixey, 'Hydrographical survey of the Northern Frontier District', I944, 6.
} 
success. ${ }^{\mathrm{I} 26}$ For instance, while stabilization projects may deliver much-needed infrastructure, there is very little evidence to suggest that they deliver increased security. ${ }^{\text {I27 }}$ Likewise, colonial securitized development delivered some improvements to the supply and distribution of water resources, and some chiefs and headmen did comply with colonial directives and movement controls. As Li reminds us, improvement schemes do bring changes that people want, including in this case, more water and better grazing. ${ }^{\text {I28 }}$ However, in general there is little evidence to suggest that these measures succeeded in keeping population movements within the province or across the frontier to a minimum, or that they helped to contain the threat of cross-border raids and migrations. According to provincial reports, 'infiltration' from Somalia not only continued after I950, but increased year on year to I958. ${ }^{\text {I29 }}$ It was only when additional security measures were put in place along the border with Somalia as a precaution against the 'threat of raids, mass infiltration and internal disturbance' in the run up to the independence of the Republic of Somalia in I960, that these unofficial movements of people were reduced, but not eliminated entirely. ${ }^{\mathrm{I}}{ }^{\circ}$

A number of reasons have been put forward to explain why development interventions do not produce intended results. One approach is that the projects conceived are not fit for purpose. ${ }^{\mathrm{I}}$ I This has already been touched upon in relation to colonial conservation, which was a major cause, rather than solution to rural degradation. ${ }^{\mathrm{I} 32}$ In NEP, there was certainly significant local resistance to the implementation of colonial grazing control policies that made little ecological sense. For one, grazing control was dependent upon climatic conditions, and only worked when adequate grazing was available across all districts. ${ }^{\text {I33 }}$ At all other times, local climatic conditions necessitated continued movement across international borders and internal resource boundaries, even when this was prohibited by control orders. In many cases local people made a calculated decision to accept prosecution under the SDAO, rather than suffer from poor grazing. ${ }^{\text {}} 34$ At the same time, the very establishment of new supplies of water by state officials created incentives for people to move across internal resource borders during times of resource scarcity. For instance, the

I26 Escobar, Encountering Development, 4; Ferguson, Anti-Politics; D. Moyo, Dead Aid: Why Aid is Not Working and How There is Another Way for Africa (London, 2010). In relation to stabilization, see Bradbury and Kleinman, Winning; Fishstein and Wilder, Winning; Barakat, Deely, and Zych, 'Tradition of forgetting', 297.

I27 Fisher and Anderson, 'Authoritarianism', I3 I; Hagmann, Stabilization, I9, 2 I.

I $28 \mathrm{Li}$, Will to Improve, I.

I29 In Garissa the number of Aulihan was estimated to have increased by 2,000 between I949 and I956. KNA PC/NFD I/I/I I, 'Northern Province annual report', I956, I, 29.

I30 KNA PC/NFD I/I/I I, 'Northern Province annual report', I957, 2; KNA, PC/NFD I/I/I 2, 'Northern Province annual report', I959, 2.

I3 I Hodge, Triumph, 210-19, 230.

I32 Beinart, 'African history', 274; McCann, Green Land, 69, I44.

I33 For example, an SDAO order to exclude the Mandera Garre from a Murille grazing area, and completely close the wells at El Wak during the rains 'worked well' during $195 \mathrm{I}$, because 'control was assisted by an abundance of rain'. KNA PC/NFD I/I/IO, 'Northern Province annual report', I95I, 47. Also see various other annual reports in KNA PC/NFD I/I/IO, PC/NFD I/I/II, and PC/NFD I/I/I 2.

I34 For example, extended drought in Wajir during the first half of I959 resulted in a 'planned' large-scale 'trespass' of Degodia into Isiolo. KNA PC/GRSSA 3/I/I 2, 'Wajir district monthly report', Mar. I959. For another example, see KNA PC/GRSSA 3/I/IO, 'Mandera district monthly report', Apr. I956. 
Mandera Degodia regularly used Dixey pans constructed for the Degodia in Wajir, and during particularly bad years, the pans also attracted use by Ajuran groups from Moyale, as well as those from across the border in Ethiopia. ${ }^{\text {I35 }}$

Nor were the colonial officials involved in development completely oblivious to the inadequacies of their policies. Colonial officials and modern developers were, and are, often well aware of the limitations of their programmes of action. ${ }^{{ }^{3} 6} \mathrm{All}$ across the development world are examples of the use of problematic policies and paradigms, despite welldocumented failure. ${ }^{\mathrm{I}}{ }^{37}$ In NEP, local officials were involved in an almost constant process of renegotiating clan based grazing zones for reasons of ecological necessity, or to accommodate population increases. ${ }^{138}$ However, rather than blame the policies for these defects, there was tendency to attribute failure to the 'habits' of the local population. ${ }^{\mathrm{I}} 39$ This is a common pseudo-explanation for the failure of development projects, which is often resorted to in an attempt to justify the routinization of development practices. ${ }^{\mathrm{I} 40}$ The persistence of cross-border raids and stock thefts in the NFD after I945, which included what the serving provincial commissioner described as one of the 'worst raids in history', certainly seemed to provide evidence of the need for more intervention, more stringent security measures, and tighter movement controls. ${ }^{\text {I4 } \mathrm{I}}$

The picture of development failure is nonetheless more complicated than poorly conceived projects. Understanding development failure also involves paying attention to the interactions between a target population and a particular project, and to the strategic uses that local actors make of them. This is what Sardan terms 'development sidetracking', and again resonates with both the modern and colonial contexts. ${ }^{\mathrm{I} 2}$ 'Sidetracking' does not imply outright resistance to a development initiative, but is a sign that the local population has appropriated a development project in keeping with their own interests and objectives, which causes unintended outcomes. ${ }^{\mathrm{I} 3}$ For instance in southern Somalia, Tobias Hagmann argues that conflict and competition among local elites for recognition and access to resources provided by external actors is one reason for the failure of stabilization operations to combat insecurity. ${ }^{\mathrm{I} 44}$ In northern Kenya since 20I0, local elites have also been accused of resource snatching, in an effort to secure exclusive access to the benefits of newly created county elective positions, as well as economic and development projects. ${ }^{145}$ Government narratives of 'opening up' the north have therefore stumbled over ethnic strategizing and violent clan competition. ${ }^{\text {. }} 6$

\footnotetext{
I 35 KNA PC/GRSSA 2/20/5, letter from DC Wajir to PC Northern Province, Io Sept. I952; KNA DC/WAJ 2/I/ 3, 'Wajir district monthly report', Feb. and June I955; KNA PC/NFD 5/2/8, Water Development Scheme; KNA PC/GRSSA $2 / 20 / 5$, letter from DC Wajir to PC Northern Province, 25 Mar. I96I. I36 See Moyo, Dead Aid.

I37 Barakat, Deely, and Zych, 'Tradition of forgetting', 297; Moyo, Dead Aid.

I3 8 Weitzberg, 'Census', 424.

I 39 KNA PC/NFD 5/2/8, Northern Frontier Water Development Scheme, 80.

I40 Sardan, Anthropology and Development, 68.

I4I KNA PC/NFD I/I/IO, 'Northern Province annual report', I952, 2.

I42 Sardan, Anthropology and Development, I40.

I 43 Ibid. I4 I-5.

I44 Hagmann, Stabilization, 23, 25.

I 45 For analysis of the 2013 election, see Carrier and Kochore, 'Navigating ethnicity'.

I46 See, for example, International Crisis Group, Kenya’s Somali North East: Devolution and Security (Brussels, $2015)$.
} 
In the colonial context, the available spoils of development were limited to water and pasture, but the exclusionary nature of colonial water and grazing schemes created a zero-sum-game in the struggle for access to scarce resources. In this case, the local elite search for power and advantages over rivals began even before projects were finalized, showing that development plans do not have to be implemented to have impacts and

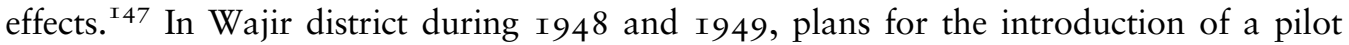
rotational grazing scheme required frequent revision as each of the district's three major clan groups made competing claims and counter-claims over customary rights to access various water and grazing resources. ${ }^{{ }^{148}}$ District officials were not always best placed to mediate these claims, due to incomplete and often contradictory information available to them in district administrative records, which created additional opportunities for those seeking to access the benefits of development. By 1956, repeated attempts to reallocate the Wajir wells, combined with works completed as part of the Dixey scheme to produce conflict between all three of the district's clan groups. Degodia groups claimed prior rights to the grazing around wells constructed for the Ajuran clan, and sought compensation by using force to drive them from nearby pans. ${ }^{\text {I49 }}$ Ajuran groups also clashed with Ogaden sections over joint grazing territory that the Ajuran claimed prior rights to, and they clashed with Degodia Rer Mohamed sections over grazing near Wajir town. ${ }^{\text {I50 }}$

Securing access to water and grazing was the dominant political issue in the lives of the people that inhabited the NFD. This was not necessarily a violent process, and it has been noted that in precolonial periods, resource users did not always fight over resources. Periods of extended drought, for example, were also often periods of peace. ${ }^{\mathrm{I}{ }^{\mathrm{I}} \mathrm{I}}$ However, having taken control over the distribution of water and grazing resources through programmes such as the Dixey scheme, allocating those resources invariably conflicted with established customary rights to wells and grazing, interrupted pre-existing relations between groups, or required amendments to be made to existing SDAO orders, all of which perpetuated the grounds over which conflicts could be fought.

This last point has particular contemporary relevance. Northern Kenya is currently regarded as a soft underbelly in the global war on terror. It has been the focus of Combined Joint Task Force-Horn of Africa development activity, and is the location of current large-scale state-led infrastructure projects. ${ }^{\mathrm{I}}{ }^{2}$ Conforming to the 'security development nexus', these projects are part of increased governmental efforts to gain political control over peripheral territories that are perceived to have economic potential, and once again the state is attempting to broadcast power through development on the

\footnotetext{
I47 H. Elliott, 'Planning, property and plots at the gateway to Kenya's "new frontier"', Journal of Eastern African Studies, I0:3 (2016), 5 I I-29, (doi: I0.1080/I753I055.20I6.I266I96).

I 48 KNA PC/GRSSA $2 / 20 / 5$, see various correspondence between the PC Northern Province and DC Wajir, as well as draft proposals for the reallocation of the Wajir wells.

I49 KNA DC/WAJ 2/I/3, 'Wajir district monthly report', June 1956.

I 50 KNA PC/GRSSA 2/20/5, letter from PC Northern Province to DC Wajir, 23 Apr. I949; KNA DC/WAJ 2/I/3, 'Wajir district monthly report', Aug. 1956.

I 5 I G. Oba, 'Resource capture: triggers of ethnic conflicts in the Northern Frontier District of Kenya, I903I903s', Journal of Eastern African Studies, 5:3 (201 I), 506.

I 52 See Browne, LAPSSET.
} 
margins. ${ }^{\mathrm{I} 33}$ However, these projects are having different impacts on the ground, including fueling conflict. ${ }^{\mathrm{I}}{ }^{4}$ Northern Kenya is an insecure area where competition for the control of resources, economic assets, and political power drives recurrent violence. ${ }^{\mathrm{I} 55}$ Development is, and as this article shows, has complicated and created new patterns of violence.

\section{CONCLUSION}

When Kenya was set on the road to independence in the early I960s, the British abandoned water and grazing schemes. However, the problems that the colonial administration sought to address through development, namely the effects of drought, migration, and resource conflict, persisted into the postcolonial era. So too have colonial methods for dealing with them. Both the Kenyan government and international development agents draw connections between environmental degradation, resource competition, and regional instability, and they have sought to deal with these problems primarily through infrastructure development. The aim is to combat potential domestic and cross-border security threats by increasing state presence and control, which includes the use of military and security forces. Then, as with now, many of these interventions have not only failed to achieve what they set out to do, but have also often made things worse.

This is not to say that differences cannot be found in the nuances of colonial and modern-day approaches to securitized development. There appears to have been a higher degree of overt coercion involved in the colonial case study, and a larger number of actors are involved in the modern-day examples (which includes international nongovernment organizations, civil society organizations, international financial institutions, bilateral and multilateral donors, government bodies, military forces, and private security companies). ${ }^{156}$ The scope of the new securitized development has also widened to include education and other social service provision. However, the 'baggage' of colonial ideas and techniques remains. More broadly too, the parallels between colonial and modern-day approaches to development in North East Africa serves as a reminder of the crucial role that experts play in formulating solutions to development problems, as well as the way that they can be used to mask the political, economic, or strategic aims of the developers.

One further continuity in both the past and present examples of securitized development is the notion of the 'ungoverned space'. Concerns still abound in Kenya over the porosity of the $680 \mathrm{~km}$ border with Somalia, which is seen as aiding the proliferation of small arms in the region, as well as enabling the expansion of Al-Shabaab activities from across the border in Somalia. ${ }^{157}$ Equally concerning from the perspective of the Kenyan government is the cross-border exchange of people, especially since the early I990s, and the growth of

I53 R. Amer, A. Swain, and J. Ojendal (eds.), The Security-Development Nexus: Peace, Conflict and Development (London, 2012).

I 54 Interview with Gufu Banchale, Marsabit, I9 Dec. 20I 5; interview with Adhi Chiwe, Marsabit, 20 Dec. 20 I 5 ; Browne, LAPSSET, 57.

I 55 See K. Menkhaus, Conflict Assessment: Northern Kenya and Somaliland (Copenhagen, 20I 5 ).

I 56 Barakat, Deely, and Zych, 'Tradition of forgetting', 3 I 2.

I 57 International Crisis Group, Devolution and Security, I-2. 
the Somali refugee population in NEP. ${ }^{158}$ This has no doubt added to the sense of the region being 'ungoverned', raising questions about who is and who is not really Kenyan among the population.

The 'ungoverned space' framework therefore not only underscores much of the thinking behind the current link-up between development and security, but also reflects wider beliefs about the different ways that development can be used to reinforce and extend state power. ${ }^{159}$ However, there are conceptual weaknesses with the 'ungoverned' paradigm. On the one hand, it ignores sophisticated indigenous forms of government, and it obscures what this article has shown to be aggressive state-building and development aspirations in these kinds of spaces. ${ }^{\text {I60 }}$ The 'ungoverned space' framework also masks the role of the state in producing the violence and instability that is supposed to define them. Interventions like water provision and grazing control (as well as infrastructure development more broadly) are not simply technologies of state power, but can be used differently by different groups of people in ways that challenge the legitimacy of that state.

\footnotetext{
I 58 Ibid. $5-6$.

I 59 See Ferguson, Anti-Politics; Herbst, States and Power; and J. Scott, Seeing Like a State: How Certain Schemes to Improve the Human Condition have Failed (London, I999).

I60 Bradbury and Kleinman, Winning, 26.
} 